\title{
The cytotoxicity of 3-bromopyruvate in breast cancer cells depends on extracellular $\mathrm{pH}$
}

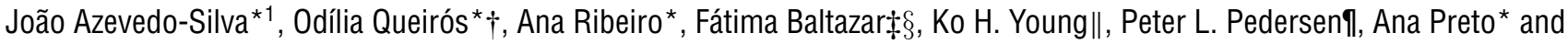 \\ Margarida Casal ${ }^{* 1}$ \\ ${ }^{*}$ Centre of Molecular and Environmental Biology (CBMA), Department of Biology, University of Minho, Campus de Gualtar, Braga 4710-057, Portugal \\ †CESPU, Instituto de Investigação e Formação Avançada em Ciências e Tecnologias da Saúde, Rua Central de Gandra, 1317, 4585-116, Gandra, PRD, Portugal \\ †Life and Health Sciences Research Institute (ICVS), School of Health Sciences, University of Minho, Campus de Gualtar, Braga 4710-057, Portugal \\ $\S$ ICVS/3B's - PT Government Associate Laboratory, Braga, 4710-057, Portugal \\ ॥KoDiscovery, LLC, University of Maryland BioPark, Suite 502 E \& F, 801 West Baltimore St., Baltimore, MD 21201, U.S.A. \\ १Departments of Biological Chemistry and Oncology, Member at Large, Sidney Kimmel Comprehensive Cancer Center, John Hopkins University, School of Medicine, Baltimore, MD \\ 21205-2185, U.S.A.
}

\begin{abstract}
Although the anti-cancer properties of 3BP (3-bromopyruvate) have been described previously, its selectivity for cancer cells still needs to be explained [Ko et al. (2001) Cancer Lett. 173, 83-91]. In the present study, we characterized the kinetic parameters of radiolabelled $\left[{ }^{14} \mathrm{C}\right] 3 \mathrm{BP}$ uptake in three breast cancer cell lines that display different levels of resistance to 3BP: ZR-75-1 < MCF-7 < SK-BR-3. At pH 6.0, the affinity of cancer cells for 3BP transport correlates with their sensitivity, a pattern that does not occur at $\mathrm{pH}$ 7.4. In the three cell lines, the uptake of 3BP is dependent on the protonmotive force and is decreased by MCTs (monocarboxylate transporters) inhibitors. In the SK-BR-3 cell line, a sodium-dependent transport also occurs. Butyrate promotes the localization of MCT-1 at the plasma membrane and increases the level of MCT-4 expression, leading to a higher sensitivity for
\end{abstract}

3BP. In the present study, we demonstrate that this phenotype is accompanied by an increase in affinity for 3BP uptake. Our results confirm the role of MCTs, especially MCT-1, in 3BP uptake and the importance of cluster of differentiation (CD) 147 glycosylation in this process. We find that the affinity for $3 \mathrm{BP}$ transport is higher when the extracellular milieu is acidic. This is a typical phenotype of tumour microenvironment and explains the lack of secondary effects of 3BP already described in in vivo studies [Ko et al. (2004) Biochem. Biophys. Res. Commun. 324, 269-275].

Key words: 3-bromopyruvate, cluster of differentiation (CD) 147, extracellular acid $\mathrm{pH}$, lactate, monocarboxylate transporter, tumour microenvironment.

\section{INTRODUCTION}

Cancer cells acquire de novo features different from normal cells, commonly referred as 'hallmarks' [1]. Unravelling these hallmarks is of extreme importance in understanding how cancer cells behave and subsequently for developing new methods for diagnosis and therapy. One such hallmark first described by Otto Warburg [2] as the origin of cancer cells is the acquisition of an aerobic glycolytic phenotype, i.e. the metabolism of the sugar glucose to lactic acid, even in the presence of oxygen. The resultant cancer cells, even in the presence of oxygen, rely somewhat more on glycolysis for energy production than normal cells but also carry out oxidative phosphorylation (OXPHOS) [3]. The elevated glycolytic rate even in the presence of oxygen resulting from this metabolic reprogramming is known as the 'Warburg effect' and, together with mitochondrial OXPHOS, is crucial for the rapid energy production that sustains high proliferative rates, providing biosynthetic precursors that support cell growth [4].

The enhanced glycolysis in cancer cells correlates with an increased expression of enzymes, e.g. hexokinase 2 (Hk-2) [5,6] and glyceraldehyde-3-phosphate dehydrogenase (GAPDH) [7], as well as transporters for glucose (GLUTs) [8] and lactate [MCTs (monocarboxylate transporters) [9,10]. Whereas GLUTs are important for the increased uptake of the glucose needed to sustain high rates of glycolysis, Hk-2 bound to the outer mitochondrial membrane rapidly phosphorylates the glucose to glucose 6-phosphate without the negative feedback observed for other hexokinase isoforms [11]. Significantly, Hk-2 is bound to the outer mitochondrial membrane via the porin-like protein VDAC (voltage-dependent anion channel). The adenine nucleotide transporter located in the inner membrane and VDAC in the outer membrane move ATP made by the mitochondrial inner membrane ATP synthase to the active site of Hk-2 bound to VDAC. Here, the ATP and glucose are converted into glucose 6-phosphate at an elevated rate. This critical metabolite then serves as both a biosynthetic precursor to support cell proliferation (via the pentose phosphate pathway) and via the glycolytic pathway as a precursor for lactate that, upon export, reduces the extracellular $\mathrm{pH}$, an event that probably contributes to the proliferation, invasion, metastasis and angiogenesis of tumour cells [6].

The high level of lactate produced via glycolysis in cancer cells needs to be exported in order to avoid intracellular acidification and cell death. Therefore, cancer cells commonly overexpress MCTs $[9,10]$. MCTs are a family of transmembrane transporters

Abbreviations: 3BP, 3-bromopyruvate; $\mathrm{AE} 1$, anion exchanger 1; CCCP, carbonyl cyanide m-chlorophenyl hydrazine; CD, cluster of differentiation; CG, core-glycosylated; CHC, $\alpha$-cyano-4-hydroxycinnamate; CP, core protein without glycosylation; DIDS, 4,4'-di-isothiocyano-2,2'-stilbenedisulfonic acid; FG, fully glycosylated; GAPDH, glyceraldehyde-3-phosphate dehydrogenase; GLUT, glucose transporter; Hk-2, hexokinase 2; MCT, monocarboxylate transporter; OXPHOS, oxidative phosphorylation; PBST, PBS with $0.1 \%$ Tween 20; SMCT, sodium monocarboxylate transporter; SRB, sulforodamine B; VDAC, voltage-dependent anion channel.

1 Correspondence may be addressed to either of these authors (email joaosilva@bio.uminho.pt or mcasal@bio.uminho.pt). 
composed of 14 members but only MCT-1, $-2,-3$ and -4 are known to participate in uptake and efflux of monocarboxylic acids via a proton-linked mechanism [12]. Whereas MCT-1 is expressed ubiquitously and is known to participate either in the uptake or in the efflux of lactate, MCT-4 is largely described as a lactate exporter. Both MCT- 1 and MCT- 4 are overexpressed in many tumours and are normally associated with their chaperone cluster of differentiation (CD) 147 [10,13-16]. CD147 needs to be glycosylated to reach the plasma membrane, otherwise it will be retained at the endoplasmic reticulum [17]. MCT-2 is a highaffinity lactate transporter that is overexpressed in cancer but only at the cytoplasmic level $[10,16]$. MCT-3 has a restricted expression in the retina [18] and has never been associated with cancer-related processes. MCTs have been described as good histological markers for cancer prognosis. They have been mentioned also as targets for therapeutic candidates either by inhibition of lactate efflux using inhibitors such as $\alpha$-cyano4-hydroxycinnamic acid (CHC) [19] and AR-C155858 [20], a specific MCT-1 inhibitor, or through the silencing of MCT gene expression [21].

MCTs can be used also for cancer therapy as Trojan horses for toxic molecules recognized as substrates for MCT transport. One such molecule is 3-bromopyruvate (3BP), an analogue of lactate and pyruvate that is known for its alkylating properties. 3BP targets energy metabolism of cancer cells, i.e. both glycolysis and mitochondrial oxidative phosphorylation, while leaving normal cells unharmed. Glycolytic targets of 3BP are both Hk-2 [22] and GAPDH [23]. 3BP's anti-tumour efficiency has been proven in vitro for different tumour models and also in vivo [22,24]. Significantly, 3BP completely eradicated cancers (hepatomas) in 19 of 19 rats $(100 \%)$ without any noticeable secondary effects [24]. Moreover, all animals lived out a normal life without the return of cancer. Also, 3BP has been used successfully in a human translational study [25] significantly extending the life of the patient. These remarkable findings warrant clinical trials involving multiple patients to fully evaluate 3BP's potential as an anti-cancer agent.

Due to the alkylating properties of 3BP, it is surprising that few secondary effects have been reported to date. This may be related to the structural similarity of 3BP to the monocarboxylic acids lactate and pyruvate that make it suitable for transport by the MCT or MCTs overexpressed in most tumours. Thus, 3BP may enter cancer cells on the same MCT on which lactate makes its exit. One study conducted by Birsoy et al. [26] reported the importance of MCTs, e.g. MCT-1, in facilitating 3BP's anticancer properties. We have shown also that 3BP's cytotoxic effect correlates with MCT expression level and that cell sensitivity to 3BP can be increased by pretreatment with butyrate. This leads to an increased expression of MCT-4 and enhances localization of MCT-1 at the plasma membrane [27]. Other studies have also reported the capacity of SMCT-1 (sodium monocarboxylate transporter), a sodium-dependent electrogenic transporter of monocarboxylates, in facilitating the uptake of 3BP despite the fact that its expression is down-regulated in cancer cells [28].

Based on all that described above, it seems clear that previous studies have provided many clues underlying the importance of MCTs in facilitating the anti-cancer properties of 3BP [26,27]. However, the kinetics of 3BP's transport across the plasma membrane at physiological and tumour-associated extracellular $\mathrm{pH}$ has not been reported. In the present study using $\left[{ }^{14} \mathrm{C}\right] 3 \mathrm{BP}$, we carried out a detailed characterization of the kinetics and energetics of 3BP transport with the objective of understanding how its transport correlates with its cytotoxic effect in cancer cells while leaving normal cells unharmed.
Table 1 List of primary and secondary antibodies conditions used in the present study

\begin{tabular}{lll}
\hline Protein & Size (kDa) & Supplier; dilution (diluent) \\
\hline MCT-1 & 43 & Santa Cruz Biotechnology; 1:500 (5\% milk) \\
MCT-4 & 43 & Santa Cruz Biotechnology; 1:500 (5\% BSA) \\
AE1 & 102 & Abcam; 1:500 (5\% milk) \\
CD147 & $45-65($ FG) & Santa Cruz Biotechnology; 1:100 (5\% milk) \\
& $35(\mathrm{CG})$ & - \\
CD44 & 83 & Serotec; 1:500 (5\% milk) \\
Hk-2 & 102 & Abcam; 1:759 (5\% milk) \\
$\beta$-Actin & 30 & Santa Cruz Biotechnology; 1:2000 (5\% BSA)
\end{tabular}

\section{MATERIAL AND METHODS}

\section{Cell lines and culture conditions}

Three breast cancer cell lines were obtained from the A.T.C.C.: MCF-7, ZR-75-1 and SK-BR-3. All cell lines were grown as monolayers at $37^{\circ} \mathrm{C}$ in a humidified incubator with $5 \% \mathrm{CO}_{2}$ and in RPMI 1640 medium (PAA Laboratories $\mathrm{GmbH}$ ) supplemented with $10 \%$ FBS (Invitrogen) and $1 \%$ penicillin/streptomycin (Invitrogen). The medium for MCF-7 was also supplemented with $25 \mu \mathrm{g} / \mathrm{ml}$ insulin (Sigma). Cells were kept in exponential growth phase and subcultured twice a week. For assays, subconfluent cells in exponential growth phase were detached with trypsin/EDTA (Invitrogen) and resuspended in fresh medium at the appropriate density.

\section{Chemicals}

3BP, butyric acid, lactic acid and tunicamycin were purchased from Sigma. Acetic acid and pyruvic acid were purchased from Merck. Radiolabelled $\left[{ }^{14} \mathrm{C}\right]$ 3BP, with a specific activity of 15.0 $\mathrm{mCi} / \mathrm{mmol}$ was purchased from PerkinElmer. Carbonyl cyanide $m$-chlorophenyl hydrazone (CCCP), monensin, valinomycin and CHC were purchased from Sigma. 4,4'-Di-isothiocyano-2,2'stilbenedisulfonic acid (DIDS) was obtained from Santa Cruz Biotechnology and AR-C155858 was a gift from AstraZeneca. The origins of the antibodies used for Western blot analysis, as well as the dilutions used, are described in Table 1.

\section{Measurement of 3BP uptake}

The protocol for $\left[{ }^{14} \mathrm{C}\right]$ 3BP uptake was adapted from that of Kobayashi et al. [29]. Briefly, cells seeded in 24-well plates at $2-3 \times 10^{5}$ cells/well and incubated overnight at $37^{\circ} \mathrm{C}$ with $5 \% \quad \mathrm{CO}_{2}$ were washed twice and incubated with HEPES buffer ( $\mathrm{pH}$ 7.4) (25 mM D-glucose, $137 \mathrm{mM} \mathrm{NaCl}, 5.37 \mathrm{mM}$ $\mathrm{KCl}, 0.3 \mathrm{mM} \mathrm{Na}_{2} \mathrm{HPO}_{4}, 0.44 \mathrm{mM} \mathrm{KH}_{2} \mathrm{PO}_{4}, 4.17 \mathrm{mM} \mathrm{NaHCO}$, $1.26 \mathrm{mM} \mathrm{CaCl}_{2}, 0.8 \mathrm{mM} \mathrm{MgSO}_{4}$ and $10 \mathrm{mM} \mathrm{HEPES}$ ) for $10 \mathrm{~min}$ at $37^{\circ} \mathrm{C}$. HEPES buffer was removed and cells were incubated in MES buffer (pH 6.0) (25 mM D-glucose, $137 \mathrm{mM} \mathrm{NaCl}, 5.37 \mathrm{mM}$ $\mathrm{KCl}, 0.3 \mathrm{mM} \mathrm{Na} \mathrm{HPO}_{4}, 0.44 \mathrm{mM} \mathrm{KH} \mathrm{PO}_{4}, 4.17 \mathrm{mM} \mathrm{NaHCO}$, $1.26 \mathrm{mM} \mathrm{CaCl}_{2}, 0.8 \mathrm{mM} \mathrm{MgSO}_{4}$ and $\left.10 \mathrm{mM} \mathrm{MES}\right)$ with the radiolabelled $\left[{ }^{14} \mathrm{C}\right] 3 \mathrm{BP}$ (4000 d.p.m./nmol) for the appropriate period of time at $37^{\circ} \mathrm{C}$. Uptake was performed in $\left[{ }^{14} \mathrm{C}\right] 3 \mathrm{BP}$ HEPES buffer (pH 7.4).

After the appropriate incubation time, the $\left[{ }^{14} \mathrm{C}\right] 3 \mathrm{BP}$ solution was removed, the plate was incubated on ice and the cultures washed with ice-cold HEPES buffer, pH 7.4. Cells were then solubilized with $1 \%$ SDS/0.2 $\mathrm{M} \mathrm{NaOH}$ and mixed with scintillation liquid for measuring radioactivity in a Packard Tri-Carb 2200 CA liquid scintillation spectrophotometer with 
d.p.m. correction. For normalization, protein of all samples was quantified using a BCA Protein Assay Kit (Pierce). Kinetic parameters were determined using GraphPad Prism 4 software for the non-linear regression of the plots of the initial uptake rates of $3 \mathrm{BP}$ as a function of the acid concentration. As $\left[{ }^{14} \mathrm{C}\right]$ $3 \mathrm{BP}$ uptake was linear up to $30 \mathrm{~min}, 15 \mathrm{~min}$ of incubation of the cells with the radio labelled substrate was adopted in the present study.

The effect of distinct inhibitors AR-C155858, CHC, DIDS, CCCP, monensin and valinomycin was evaluated in cells incubated for $3 \mathrm{~min}$ with each compound in MES buffer, $\mathrm{pH}$ 6.0, prior to incubation with $1.0 \mathrm{mM}\left[{ }^{14} \mathrm{C}\right] 3 \mathrm{BP}$ for $15 \mathrm{~min}$. The inhibitory effect of lactate and pyruvate $(10 \mathrm{mM})$ was evaluated by mixing each acid with $1.0 \mathrm{mM}\left[{ }^{14} \mathrm{C}\right] 3 \mathrm{BP}$ in MES buffer, pH 6.0.

\section{Butyrate pretreatment}

Cells were seeded at $1.5 \times 10^{5}$ cells/well in a 24 -well plate and allowed to attach overnight. Then, the medium was replaced by fresh medium containing butyrate at $10 \mathrm{mM}$. After $24 \mathrm{~h}$ of incubation, the kinetics of 3BP uptake was evaluated. Cells cultivated under the same conditions, but without the addition of butyrate, were used as a control.

\section{SRB cell survival assay}

After $24 \mathrm{~h}$ of growth in RPMI 1640 medium, the cells seeded in 96-well plates, were treated with a series of 3BP concentrations in RPMI 1640 medium buffered with HEPES at pH 6.0 and 7.4. To the evaluation of the effect of AR-C155858 on 3BP cytotoxicity, the compound was added to different concentrations of $3 \mathrm{BP}$ in RPMI 1640 medium. After $16 \mathrm{~h}$ of treatment, cells were fixed with a solution of $1.0 \%$ acetic acid in methanol for $90 \mathrm{~min}$ at $-20^{\circ} \mathrm{C}$. After washing with PBS and air-drying, the fixed cells were stained with $0.4 \%$ sulforodamine B (SRB; Sigma) for 90 min at $37^{\circ} \mathrm{C}$. Cells were then rinsed with $1.0 \%$ acetic acid and air-dried. The bound dye was solubilized with $10 \mathrm{mM}$ Tris/ $\mathrm{HCl}$ and the absorbance was measured at $540 \mathrm{~nm}$. The percentage of surviving cells was determined by comparing the absorbance of the treated cells to the untreated cells (corresponding to $100 \%$ of viable cells) for each $\mathrm{pH}$. At least three independent experiments were performed, each in triplicate and $\mathrm{IC}_{50}$ values were estimated using GraphPad Prism 4 software, applying a sigmoidal doseresponse (variable slope) non-linear regression, after logarithmic transformation.

\section{Protein expression analysis}

The expression of MCT-1, MCT-4, CD147, CD44, AE1 and Hk-2 was assessed by Western blot analysis. Cells were seeded in 60$\mathrm{mm}$ plates at $1.5-2.0 \times 10^{6}$ cells/plate and incubated at $37^{\circ} \mathrm{C}$, $5 \% \mathrm{CO}_{2}$. After $24 \mathrm{~h}$, cells were washed with ice-cold PBS, collected by scrapping and then centrifuged at $2000 \mathrm{~g}$ for $5 \mathrm{~min}$. Supernatants were discarded and ice-cold lysis buffer $[150 \mathrm{mM}$ $\mathrm{NaCl}, 0.1 \mathrm{mM}$ EDTA, $1 \%$ Triton X-100, 1\% NP40, $50 \mathrm{mM}$ Tris/HCl, pH 7.5 and $1 / 7$ protease inhibitor cocktail (Roche Applied Sciences)] was added. The lysates were incubated at $4{ }^{\circ} \mathrm{C}$ for $15 \mathrm{~min}$ and then centrifuged at $13000 \mathrm{~g}$ for $15 \mathrm{~min}$. Supernatants were collected for protein analysis and quantified using the Pierce BCA Protein Assay Kit.

Western blot analysis was performed according to conventional protocols. Protein samples were separated by $10 \%$ acrylamide SDS/PAGE and after separation, transferred on to PVDF membranes (Millipore). When the transfer was completed, membranes were washed in PBS with $0.1 \%$ Tween 20 (PBST) and blocked in $5.0 \%$ skimmed milk solution for $1 \mathrm{~h}$ at room temperature. After proper rinsing in PBST, the membranes were incubated over-night at $4{ }^{\circ} \mathrm{C}$ with primary antibodies for the proteins described above. The antibody dilutions used are presented in Table 1. Then, membranes were washed three times with PBS and incubated for $1 \mathrm{~h}$ at room temperature with the proper secondary antibody, conjugated with horseradish peroxidase. The immunoreactive proteins were visualized using the enhanced chemiluminescence detection kit (Millipore), in an imaging system (Chemidoc, Bio-Rad Laboratories). Protein content was analysed using ImageJ software (NIH) by measuring the density of each band and then normalizing to the actin content.

\section{Tunicamycin inhibition of CD147}

The inhibition of CD147 glycosylation was obtained using tunicamycin, an inhibitor of N-glycosylation in ZR-75-1 cell line. Cells were seeded in 24- and six-well plates for 3BP uptake assays and protein expression analysis respectively, as already described. After overnight incubation to allow cell attachment, the medium was replaced by fresh medium containing crescent concentrations of tunicamycin $(0,2,5,10$ and $20 \mu \mathrm{g} / \mathrm{ml})$. Cells were incubated for 48, 72 and $96 \mathrm{~h}$ and further used for 3BP uptake and protein extraction for Western blot analysis.

\section{Statistical analysis}

To evaluate the differences in the kinetic parameters $\left(K_{\mathrm{m}}\right.$ and $\left.V_{\max }\right)$ of each cell line, a one-way ANOVA with Tukey's post-test was used. For analysing the results of the inhibition of 3BP uptake were utilized a one-way ANOVA with Dunnett's post-hoc test comparing all drug to the control. The effect of tunicamycin in the 3BP uptake inhibition was analysed by two-way ANOVA.

\section{RESULTS}

\section{Kinetics and energetics of 3BP uptake across the plasma membrane in breast cancer cell lines}

The initial uptake rates of $\left[{ }^{14} \mathrm{C}\right] 3 \mathrm{BP}$ at $\mathrm{pH} 6.0$ and $\mathrm{pH} 7.4$ (Figure 1) evaluated in ZR-75-1, MCF-7 and SK-BR-3 breast cancer cell lines followed Michaelis-Menten-like kinetic profiles. At $\mathrm{pH} \mathrm{7.4,} \mathrm{no} \mathrm{statistical} \mathrm{significance} \mathrm{was} \mathrm{found} \mathrm{for} \mathrm{variations}$ detected both in $K_{\mathrm{m}}$ and in $V_{\max }$ values for the three cell lines. Regarding the capacity for 3BP transport at $\mathrm{pH} 6.0$, the distinct values for $V_{\max }$ showed no statistically valid difference. However, at $\mathrm{pH} 6.0$, the $K_{\mathrm{m}}$ for 3BP uptake in SK-BR-3 was $2.11 \pm 0.62 \mathrm{mM}$, a value significantly higher $(P<0.05)$ than those estimated for the ZR-75-1 and MCF-7 cell lines, $0.57 \pm 0.16 \mathrm{mM}$ and $0.70 \pm 0.12 \mathrm{mM}$ respectively. These results indicate that the affinity for 3BP transport at acidic $\mathrm{pH}$ is distinct in the different breast cancer cell lines.

To evaluate the energetics of $\left[{ }^{14} \mathrm{C}\right] 3 \mathrm{BP}$ transport we tested the influence of different agents known to disrupt the membrane electrochemical potentials (Figure 2), such as CCCP (a protonophore which disrupts both the $\mathrm{pH}$ and the electric potentials), monensin (an ionophore that specifically disrupts an $\mathrm{Na}^{+}$gradient) and valinomycin (an ionophore which preferentially affects a $\mathrm{K}^{+}$gradient and, to a lesser extent, an $\mathrm{Na}^{+}$ gradient across biological membranes).

CCCP impaired 3BP uptake in all cell lines (Figure 2, light grey bars), with a more pronounced effect in the SK-BR-3 cells. Here, 
A

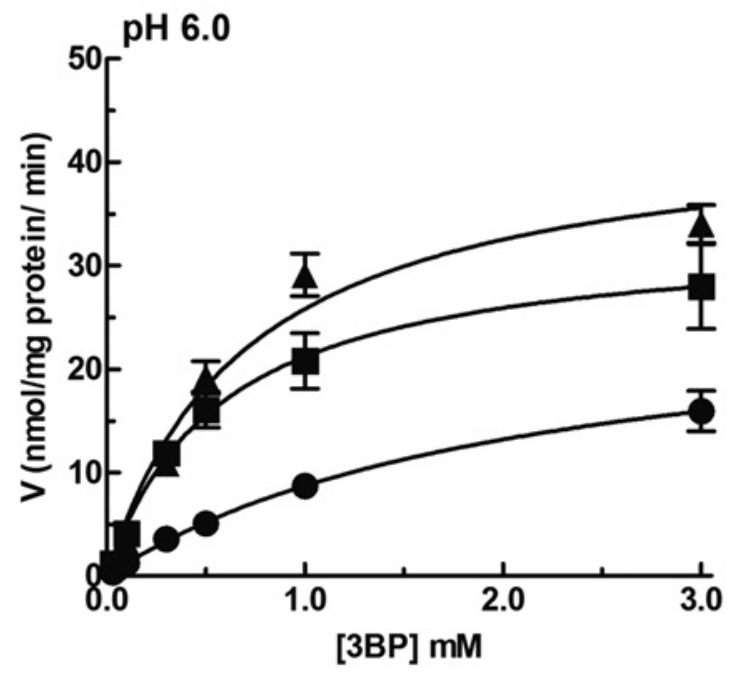

B

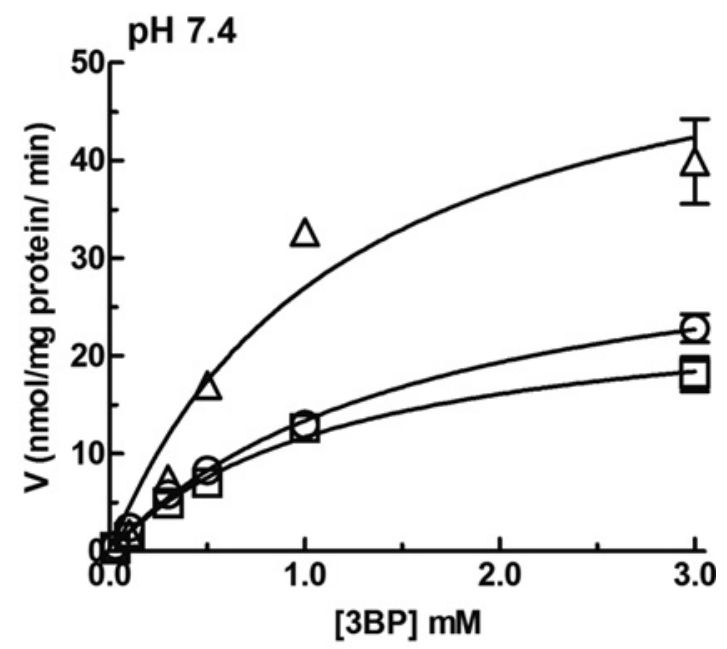

C

\begin{tabular}{clcc}
\multicolumn{2}{c}{ pH 6.0 } & \multicolumn{1}{c}{$K_{\mathrm{m}}(\mathrm{mM})$} & $V_{\max }(\mathrm{nmol} / \mathrm{mg}$ protein $/ \mathrm{min})$ \\
\cline { 2 - 4 } $\boldsymbol{\square}$ & ZR-75-1 & $0.57 \pm 0.16$ & $33 \pm 3$ \\
\hline $\boldsymbol{\Delta}$ & MCF-7 & $0.70 \pm 0.12$ & $44 \pm 3$ \\
\hline $\boldsymbol{\bullet}$ & SK-BR-3 & $2.11 \pm 0.62^{\star}$ & $27 \pm 4$ \\
\hline
\end{tabular}

\begin{tabular}{|c|c|c|c|}
\hline \multicolumn{2}{|c|}{ pH 7.4} & $K_{m}(m M)$ & $V_{\max }(\mathrm{nmol} / \mathrm{mg}$ protein $/ \mathrm{min})$ \\
\hline$\square$ & ZR-75-1 & $1.10 \pm 0.25$ & $26 \pm 1$ \\
\hline$\Delta$ & MCF-7 & $1.30 \pm 0.29$ & $63 \pm 7$ \\
\hline 0 & SK-BR-3 & $1.62 \pm 0.21$ & $31 \pm 2$ \\
\hline
\end{tabular}

Figure 1 Kinetics of radiolabelled 3BP uptake at pH 6.0 and 7.4 in breast cancer cell lines ZR-75-1, MCF-7 and SK-BR-3

(A and $\mathbf{B})$ Plots of the initial uptake rates of radio labelled 3BP as a function of the acid concentration at pH $6.0(\mathbf{A})$ and pH $7.4(\mathbf{B})$. (C) Kinetic parameters, as affinity constant $\left(K_{\mathrm{m}}\right)$ and transport capacity $\left(V_{\max }\right)$ for the uptake of 3BP. Values were estimated with GraphPad Prism software based on the non-linear regression for the Michaelis-Menten equation $f[V]=\left(V_{\max } \times[3 B P]\right) /\left(K_{m}+\right.$ [3BP]). Statistical analysis was performed by one-way ANOVA with Tukey's post-hoc test comparing the $K_{\mathrm{m}}$ and $V_{\max }$ values of each cell line. *Significant differences with $P<0.05(n=3)$.

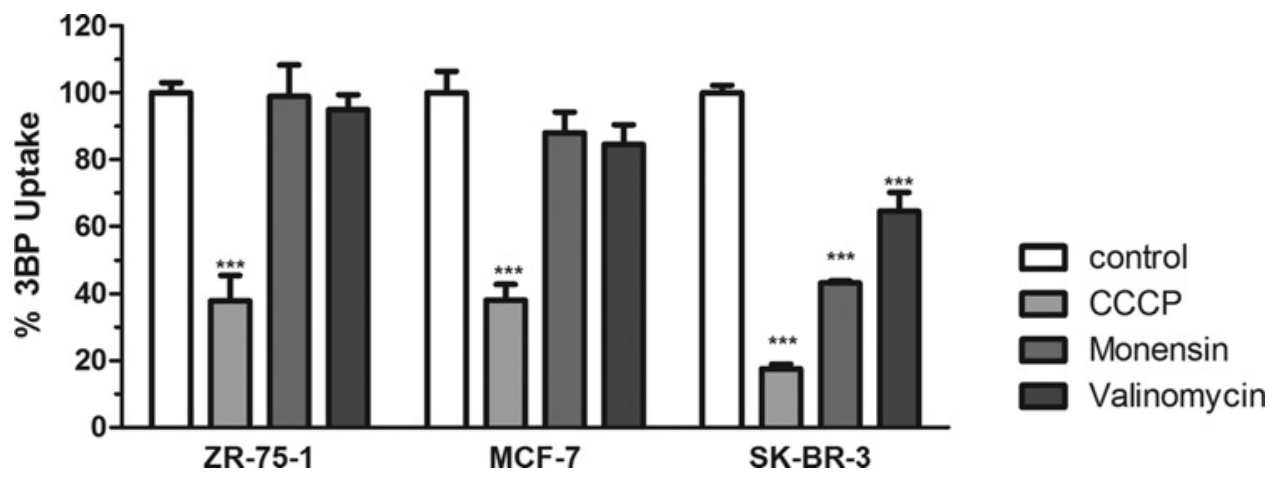

Figure 2 Effect of protonophores and ionophores on the uptake of $1 \mathrm{mM}$ radiolabelled $3 \mathrm{BP}$ at pH 6.0

CCCP and monensin were used at $100 \mu \mathrm{M}$ and valinomycin at $50 \mu \mathrm{M}$. The results are presented using as reference the uptake of $1 \mathrm{mM} 3 \mathrm{BP}$ without other compound addition (control). Statistical analysis was performed by one-way ANOVA with Dunnett's post-hoc test comparing all drugs to the control condition. ${ }^{\star \star \star}$ Significant differences with $P<0.001$ ( $n=3$ ). 
$82 \%$ inhibition of uptake was observed whereas $52 \%$ inhibition was found in both the ZR-75-1 and the MCF-7 cells. Monensin and valinomycin were very effective as inhibitors of 3BP uptake in the SK-BR-3 cells (57\% and $65 \%$ inhibition respectively), with small inhibitory effects on 3BP uptake in MCF-7 and ZR-75-1 cells. These results indicate that $3 \mathrm{BP}$ uptake requires a proton gradient in the three cell lines and also an $\mathrm{Na}^{+}$gradient in the SK-BR-3 cell line.

\section{The effect of MCT inhibitors on 3BP uptake and cytotoxicity}

To further characterize the mechanism of 3BP transport and its dependency on one or more MCTs, we tested classic MCT inhibitors (Figure 3A) such as CHC, DIDS, the specifically designed inhibitor AR-C155858, as well as 3BP's natural analogues pyruvate and L-lactate. CHC is an MCT-1 inhibitor which also inhibits SMCT-1; DIDS inhibits MCTs and anion exchangers; AR-C155858 is an inhibitor developed by AstraZeneca specific for MCT-1 and MCT-2 in a mechanism that involves intracellular binding at transmembrane helices 7-10 [30].

AR-C155858 inhibited 3BP uptake very strongly in both ZR$75-1$ cells (69\%) and MCF-7 cells (79\%) and only slightly in SKBR-3 cells ( $31 \%)$. The compound DIDS under these conditions had a very weak effect on $3 \mathrm{BP}$ uptake, with no statistically significant difference between the three cell lines $(3 \%$ in $\mathrm{ZR}$ $75-1,13 \%$ in MCF-7 and $17 \%$ in SK-BR-3; Figure 3A).

When the experiments were performed in the presence of $10 \mathrm{mM}$ lactate, cells retained $84 \%$ (ZR-75-1), $74 \%$ (MCF-7) and $65 \%$ (SK-BR-3) of their 3BP uptake capacity; on the other hand, in the presence of pyruvate $(10 \mathrm{mM}) \mathrm{ZR}-75-1$ cells retained $67 \%$, MCF-7 51\% and SK-BR-3 50\% of their 3BP uptake capacity compared with the control. Overall, these results indicate that both ZR-75-1 and MCF-7 cells display a similar inhibitory pattern for 3BP uptake which probably relies on MCT-1 as AR-C155858 led to a higher level inhibition in contrast with what is observed in SK-BR-3 cells. Together with the data obtained with the use of ionophores, it is possible to postulate that SK-BR-3 cells display a mechanism for 3BP transport distinct from that used in both ZR-75-1 and MCF-7 cells.

We also evaluated the effect of the MCT-1 inhibitor ARC155858 on the cytotoxic capacity of 3BP in ZR-75-1 and SKBR-3. The experiments were performed using low and high doses of $3 \mathrm{BP}$ in combination with $1 \mu \mathrm{M}$ inhibitor and the results were expressed as percentage survival (Figures $3 \mathrm{~B}$ and $3 \mathrm{C}$ respectively). In the $\mathrm{ZR}-75-1$ cell line, 3BP alone decreased cell survival as expected showing $89 \%$ with $30 \mu \mathrm{M}, 66 \%$ with $60 \mu \mathrm{M}$ and $18 \%$ with $150 \mu \mathrm{M}$. Treatment with the inhibitor AR$\mathrm{C} 155858$ led to an increase in cell survival to $92 \%$ at $30 \mu \mathrm{M}$, $88 \%$ at $60 \mu \mathrm{M}$ and $86 \%$ at $150 \mu \mathrm{M} 3 \mathrm{BP}$ (Figure 3B). In SKBR-3 cells, $79 \%$ survived with $250 \mu \mathrm{M} 3 \mathrm{BP}, 62 \%$ with $500 \mu \mathrm{M}$ and $34 \%$ with $2000 \mu \mathrm{M}$ and AR-C155858 did not affect the normal cell growth. However, 3BP's cytotoxic effect was further compromised in the presence of the MCT-1 inhibitor at all 3BP concentrations tested (Figure $3 \mathrm{C}$ ). The increased resistance to 3BP treatment observed with AR-C155858-treated cells led us to conclude that MCT-1 plays a crucial role in 3BP uptake, thus affecting the cytotoxicity of $3 \mathrm{BP}$ as an anti-cancer agent.

\section{Cytotoxicity of 3BP depends on extracellular pH}

The cytotoxic effect of 3BP has been reported at $\mathrm{pH} 7.4$ [27], in the three cell lines analysed. As we have observed the influence of $\mathrm{pH}$ on 3BP uptake, we re-evaluated its cytotoxicity in cells cultivated in RPMI 1640 medium buffered with HEPES both at pH 6.0 and at pH 7.4 (Figure 4). Although the pattern of cytotoxicity is maintained with ZR-75-1 cells being the most sensitive and SK-BR-3 cells the most resistant to 3BP, the decrease in the extracellular $\mathrm{pH}$ from 7.4 to 6.0 promoted a decrease in the $\mathrm{IC}_{50}$ values for 3BP cytotoxicity in all cell lines (34\% for ZR-75-1, $19 \%$ for MCF-7 and $44 \%$ for SK-BR-3). These results clearly reinforce the conclusion that tumour extracellular $\mathrm{pH}$ influences the anti-cancer cytotoxicity of 3BP.

\section{Metabolism-related proteins expression profiles}

To better understand the mechanisms underlying the distinct range of $\mathrm{IC}_{50}$ values for 3BP found for the three cells lines and how they are associated with the mechanisms of transport of 3BP across the plasma membrane, we analysed via Western blot analysis the expression patterns of MCTs and related proteins, namely CD147, CD44, AE1 and also Hk-2. The results presented in Figure 5 were processed using $\beta$-actin as an internal control and the values are presented, using as reference $(100 \%)$, the expression profiles found in the ZR-75-1 cell line as, with the exception of Hk-2, this cell line always presented a higher level of expression of the assayed proteins than the other cell lines.

Relative to the ZR-75-1 cell line, the expression levels of MCT- 1 were $69 \pm 11 \%$ in MCF-7 and $82 \pm 26 \%$ in SK-BR-3. Relative to ZR-75-1 expression, MCT-4 expression was found to be $10 \pm 3 \%$ in MCF-7 and $39 \pm 8 \%$ in SK-BR-3. The expression of glycoprotein CD44 was found to be at similar levels in ZR75-1 and MCF-7 $(82 \pm 20 \%)$ and at lower levels in SK-BR-3 $(25 \pm 1 \%)$. The chaperone CD147, important for MCT-1 and MCT-4 activity, was present in both fully glycosylated (FG) and core-glycosylated (CG) forms in ZR-75-1 at greater levels than in MCF-7 (FG: $12 \pm 4 \%$, CG: $69 \pm 11 \%$ ) and in SK-BR-3 (FG: $-13 \pm 4 \%$, CG: $12 \pm 1 \%$ ). Expression of anion exchanger 1 (AE1) was found in similar levels in ZR-75-1 and MCF-7 $(29 \pm 1 \%)$, but was not present in SK-BR-3 cells. Hk-2 was present in all cell lines but at a low amount in MCF-7 (57 $\pm 25 \%)$ and in higher levels in SK-BR-3 (264 $\pm 80 \%)$. Overall, regarding the proteins assessed, it was found that SK-BR-3 cells, the most resistant to a cytotoxic effect of $3 \mathrm{BP}$, display a very low expression for CD44, CD147 (both forms) and AE1 and a higher expression of $\mathrm{Hk}-2$ relative to ZR-75-1 and MCF7 cells.

\section{Butyrate pretreatment on 3BP transport}

We demonstrated previously that butyrate pretreatment of SKBR-3 cells leads to an increased cytotoxic effect of 3BP [27]. This phenotype was accompanied by the up-regulation of MCT-4 expression and an increased localization of MCT-1 in the plasma membrane [27]. We hypothesized that butyrate may be altering 3BP transport. Therefore, we monitored the kinetics of 3BP uptake for $24 \mathrm{~h}$ in the three different breast cancer cell lines, with and without treatment with $10 \mathrm{mM}$ butyrate (Figure 6). Significantly, in all cell lines, we found an increased affinity for 3BP uptake via a decrease in $K_{\mathrm{m}}$ values (Figure 6B). However, only in the case of the SK-BR-3 cell line was the decrease in the $K_{\mathrm{m}}$ statistically significant. In the SK-BR-3 cells, the $K_{\mathrm{m}}$ for $3 \mathrm{BP}$ uptake shifts from 2.16 to $0.65 \mathrm{mM}$ demonstrating that the effect of butyrate on this MCT's expression is related directly to the cytotoxicity of 3BP that increases the affinity for 3BP uptake. The $K_{\mathrm{m}}$ for SK-BR-3 cells treated with butyrate decreased to values similar to those presented by the ZR-75-1 and MCF-7 cell lines without butyrate treatment. Surprisingly, an increase in the glycosylation of CD147 was found also under these conditions (Figure 7). 
A

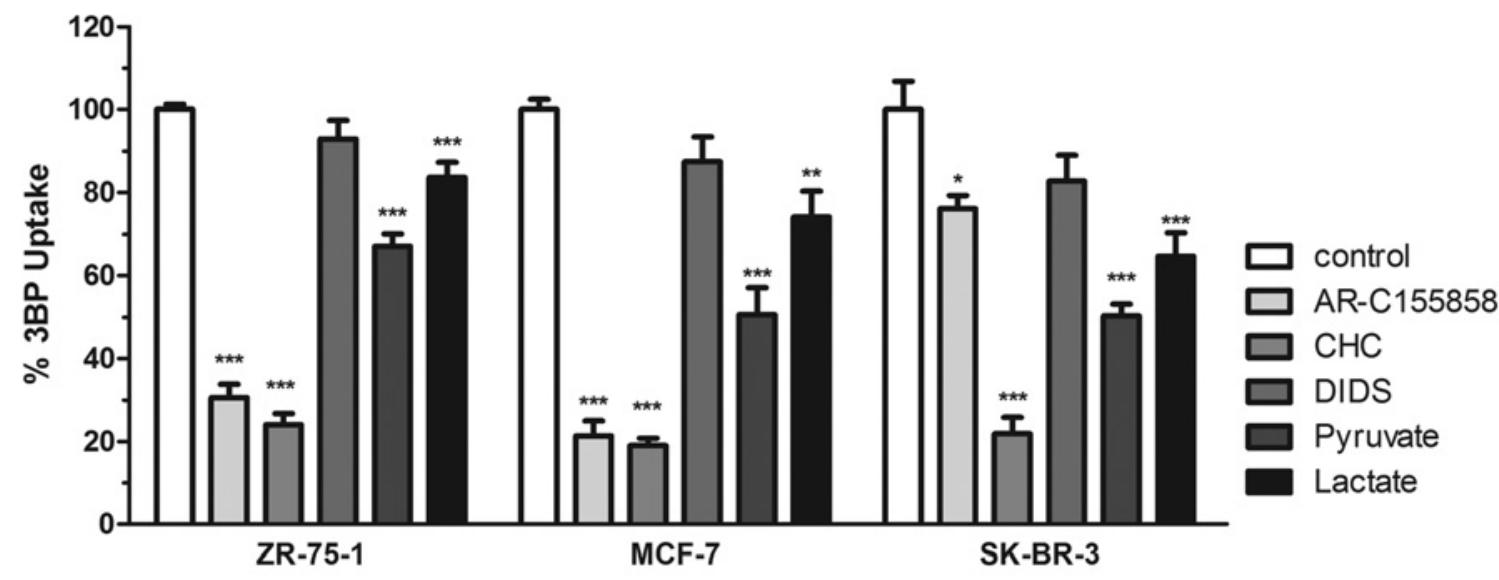

B

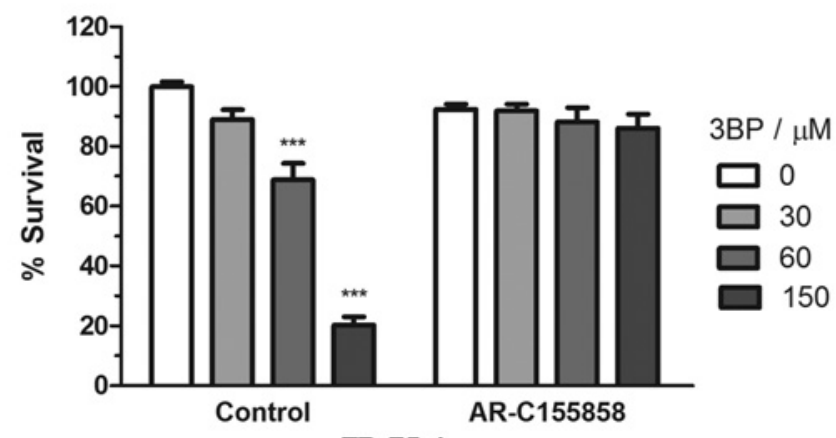

ZR-75-1
C

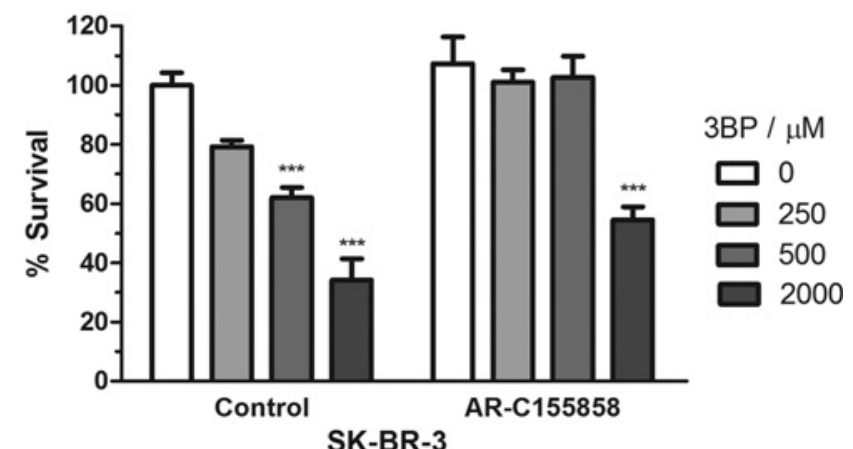

SK-BR-3

Figure 3 Effect of MCT inhibitors on 3BP uptake and cytotoxicity

(A) Inhibition of radiolabelled 3BP (1 mM) uptake by AR-C155858 $(1 \mu \mathrm{M})$, CHC $(10 \mathrm{mM})$, pyruvate $(10 \mathrm{mM})$ and lactate $(10 \mathrm{mM})$ and DIDS $(1 \mathrm{mM})$. The results are presented using as reference the uptake of $1 \mathrm{mM}$ of 3BP without other compound addition (control). (B) Effect of AR-C155858 $(1 \mu \mathrm{M})$ in the cytotoxicity of 3BP in the ZR-75-1 cell line. (C) Effect of AR-C155858 (1 $\mu \mathrm{M})$ in the cytotoxicity of 3BP in the SK-BR-3 cell line. In (B and C) results are expressed as percentage survival assuming the condition without addition of any compound as $100 \%$ survival. Statistical analysis was performed by one-way ANOVA with Dunnett's post-hoc test comparing all drugs to the control. ${ }^{* \star \star}$, ${ }^{\star \star}$ and ${ }^{*}$ indicate significant differences with respective $P$-values of $<0.001,<0.01$ and $<0.05(n=3)$.

\section{Inhibition of CD147 glycosylation in ZR-75-1 cells}

In order to understand how CD147 glycosylation influences the uptake of 3BP, we attempted to inhibit its glycosylation in the ZR-75-1 cell line, which present higher levels of CD147, using tunicamycin. We could inhibit the glycosylation of de novo synthesized CD147 as we were able to detect a band of $27 \mathrm{kDa}$ corresponding to the core protein CD147 without glycosylation (CP) when tunicamycin is added (Figure 8A). The Western blots for CD147 expression in each time point correspond to the same membrane with a lower exposure time for the $\mathrm{CP}$ form and a higher exposure time for FG and CG CD147 (Figure 8A). To overcome the influence of the glycosylated CD147 already present in cells by the time of treatment, we have evaluated different time points. We could observe that the levels of CD147 FG and CG diminish with time in cells treated with tunicamycin in comparison with untreated cells (Figure 8A). The decrease in glycosylated CD147 was followed by a decrease in the expression of MCT-1 being more evident for higher concentrations of tunicamycin.

The evaluation of 3BP uptake at $48 \mathrm{~h}$ of incubation with tunicamycin resulted in a low, but statistically significant, inhibition at the concentrations of $10 \mu \mathrm{g} / \mathrm{ml}(73 \%)$ and $20 \mu \mathrm{g} / \mathrm{ml}$ ( $83 \%$ ), but not at $2 \mu \mathrm{g} / \mathrm{ml}(96 \%)$ or $5 \mu \mathrm{g} / \mathrm{ml}(88 \%)$ ). At $72 \mathrm{~h}$,
3BP uptake was significantly inhibited with $2 \mu \mathrm{g} / \mathrm{ml}(76 \%)$ and $20 \mu \mathrm{g} / \mathrm{ml}(75 \%)$ but not with $5 \mu \mathrm{g} / \mathrm{ml}(85 \%)$ and $10 \mu \mathrm{g} / \mathrm{ml}$ $(90 \%)$ of tunicamycin. At $96 \mathrm{~h}$, tunicamycin successfully inhibited 3BP uptake at all concentrations tested $(2 \mu \mathrm{g} / \mathrm{ml}, 64 \%$; $5 \mu \mathrm{g} / \mathrm{ml}, 51 \% ; 10 \mu \mathrm{g} / \mathrm{ml}, 39 \% ; 20 \mu \mathrm{g} / \mathrm{ml}, 14 \%$ ).

\section{DISCUSSION}

The results of the present study focused on better understanding, the underlying basis of the anti-cancer cytotoxicity 3BP, towards breast cancer employing three different cell lines has led us to the following four conclusions.

\section{Extracellular acidic $\mathrm{pH}$ is important for $3 \mathrm{BP}$ selectivity}

We have characterized the kinetics of 3BP uptake in breast cancer cell lines ZR-75-1, MCF-7 and SK-BR-3 at pH 6.0 and 7.4 (Figure 1). These cells had been characterized previously for 3BP cytotoxicity [27] and found to present different levels of sensitivity: ZR-75-1 > MCF-7 > SK-BR-3. The transport of 3BP obeys classical Michaelis-Menten kinetics for one transporter, 
A
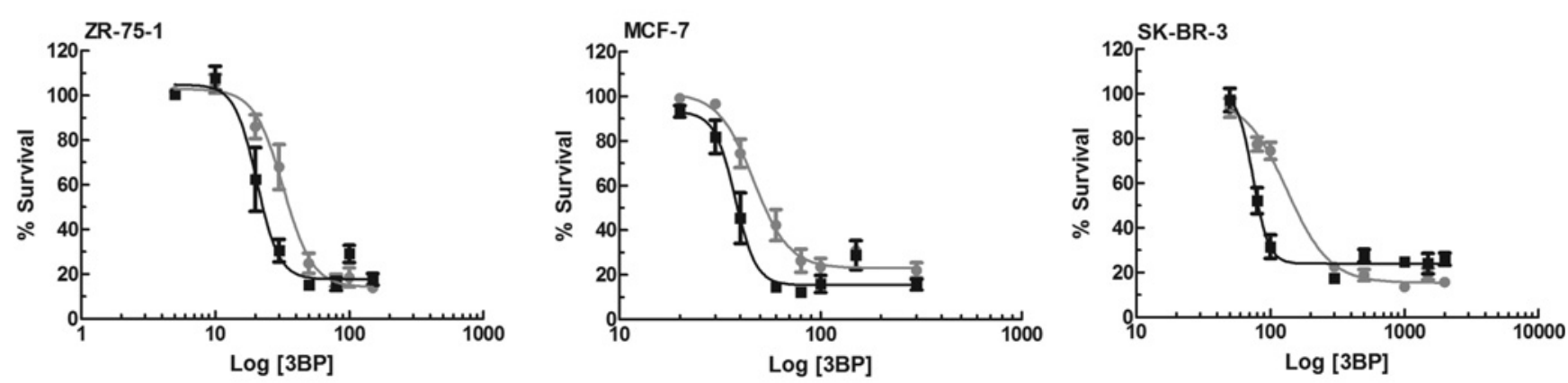

B

\begin{tabular}{lcc} 
& \multicolumn{2}{c}{$\mathrm{IC}_{50} / \mu \mathrm{M}$} \\
\cline { 2 - 3 } & $\mathbf{0} 6.0$ & $\bullet 7.4$ \\
\hline ZR-75-1 & $21 \pm 5$ & $32 \pm 8$ \\
\hline MCF-7 & $38 \pm 7$ & $47 \pm 10$ \\
\hline SK-BR-3 & $74 \pm 8$ & $133 \pm 11$ \\
\hline
\end{tabular}

Figure 4 Effect of 3BP on cell viability of the breast cancer cell lines ZR-75-1, MCF-7 and SK-BR-3 at extracellular pH 6.0 or 7.4, evaluated by the SRB assay

(A) Graphic representation of the percentage survival as a function of the 3BP concentration after logarithmic transformation. (B) IC ${ }_{50}$ values estimated by applying a sigmoidal dose-response (variable slope) non-linear regression $(n=3)$.

but the cells' behaviour differed at different $\mathrm{pH}$ values. Whereas at $\mathrm{pH} 7.4$ all cell lines presented a similar $K_{\mathrm{m}}$ for $3 \mathrm{BP}$, at $\mathrm{pH} 6.0$ a significant difference was observed. The cell lines ZR-75-1 and MCF-7 that were more sensitive to 3BP presented a 4-fold lower $K_{\mathrm{m}}$ for $3 \mathrm{BP}$ transport than the SK-BR-3 cell line. This result indicates that differences in affinity for $3 \mathrm{BP}$ uptake may underlie its cytotoxic effect, i.e. cells with higher affinity (lower $K_{\mathrm{m}}$ ) for $3 \mathrm{BP}$ uptake may be more prone to $3 \mathrm{BP}$ cytotoxicity. From results obtained by studying the effect of protonophores and ionophores on 3BP uptake (Figure 2), it was evident that at least two mechanisms may be involved in its transport. In the cell lines ZR-75-1 and MCF-7, a proton-linked symport occurs, whereas in the cell line SK-BR-3, a pH-independent transport mechanism is also present, most probably a sodium-linked mechanism. We have also evaluated the influence of glucose concentration in the 3BP uptake buffers. As described by Sonveaux et al. [31], tumours are metabolically heterogeneous presenting glycolytic and oxidative regions between which a lactate MCT-1 pathway exists. As glucose availability can alter the metabolic profile and MCT expression, we have measured the kinetics of 3BP uptake in the presence and absence of glucose in ZR-75-1 and SK-BR-3 cell lines. In both cells, the kinetics of 3BP uptake followed the same pattern observed either in the presence or in the absence of glucose, without alterations regarding affinity or velocity of 3BP transport (results not shown).

There are several studies in normal and in cancer cells that have reported the uptake of monocarboxylic acids, including 3BP, through MCTs. Most report that at extracellular $\mathrm{pH} 5.5-$ 6.5 , the uptake of carboxylic acids by MCTs is considerably higher than that observed at $\mathrm{pH} 7.0-7.5[26,29,32]$. In the present study, we show for the first time that at $\mathrm{pH} 6.0$, the affinity for 3BP transport is higher than at physiological $\mathrm{pH}$ (i.e. $\mathrm{pH} 7.4$ ). This fact is important for better understanding the mechanism of 3BP's effective and rapid killing action towards cancer and perhaps important also in giving a crucial clue to understanding the absence of noticeable side effects observed in in vivo studies in normal tissues [24]. Due to its high glycolytic phenotype, a tumour's extracellular environment is commonly acidic, a feature that promotes 3BP's action including its transport by MCTs through the plasma membrane of cancer cells with high affinity. We also observed that 3BP cytotoxicity is about the same at both $\mathrm{pH} 6.0$ and 7.4, but with a higher sensitivity at pH 6.0 (Figure 4). At $\mathrm{pH} 7.4$, the transport of 3BP occurs with lower affinity. This suggests that higher doses of 3BP may be needed relative to those used at $\mathrm{pH}$ 6.0. Thus, it is possible to postulate that under the in vitro conditions used in the present study, we also have to take into account the fact that, even at $\mathrm{pH} \mathrm{7.4,} \mathrm{cancer} \mathrm{cells} \mathrm{will}$ metabolize glucose to lactate which is then exported coupled with protons. This will lead to a reduction in $\mathrm{pH}$ of the external medium favouring the uptake of 3BP. The higher the proton availability in the extracellular environment, the more the inward symport flux of protons will be favoured and thus 3BP-mediated uptake via MCTs. Therefore, based on our results, we propose that the specific cytotoxic effect of 3BP towards cancer cells is directly related to its transport across the plasma membrane dependent on an acidic extracellular $\mathrm{pH}$ that increases the affinity for 3BP uptake. In addition, we speculate that the results of the present study may be very significant in designing future anti-cancer 3BP treatment protocols for cancer patients in a clinical setting. Due to the high affinity and selectivity of cancer cells for 3BP uptake, low dosages can be used, thus avoiding potential side effects and systemic treatments should be less problematic.

\section{Higher sensitivity to 3BP is accompanied by higher expression of MCT-related proteins}

The use of inhibitors of MCTs (Figure 3A) indicates that in the ZR-75-1 and MCF-7 cells the transport of 3BP occurs via MCTs, with MCT-1 being the most probable player. Thus, 
A

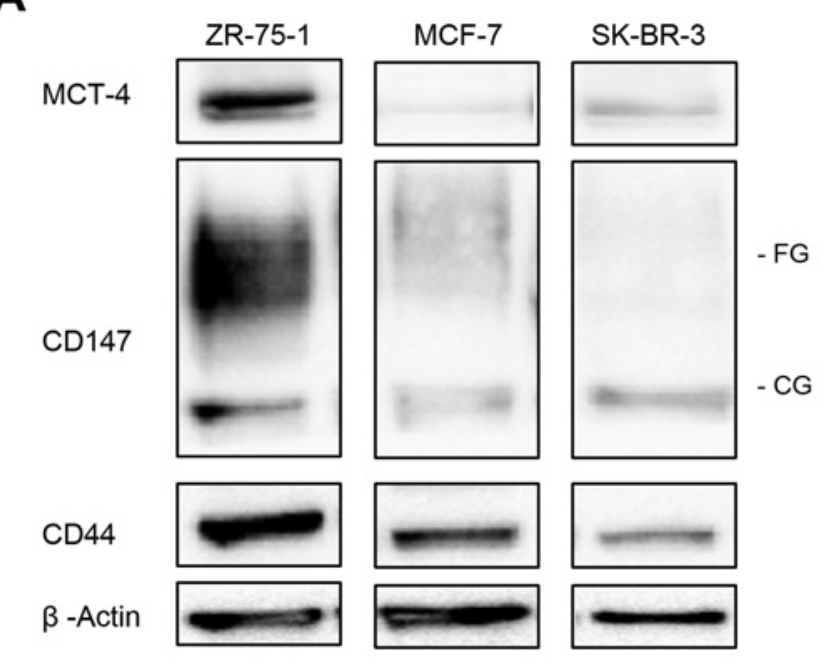

B

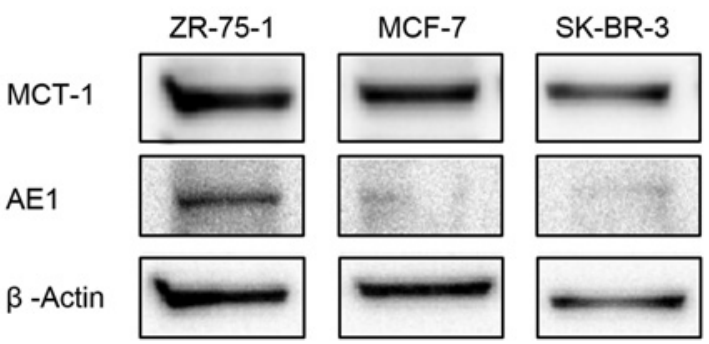

C

ZR-75-1

MCF-7

SK-BR-3

Hk-2
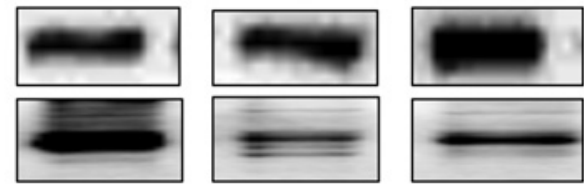

D

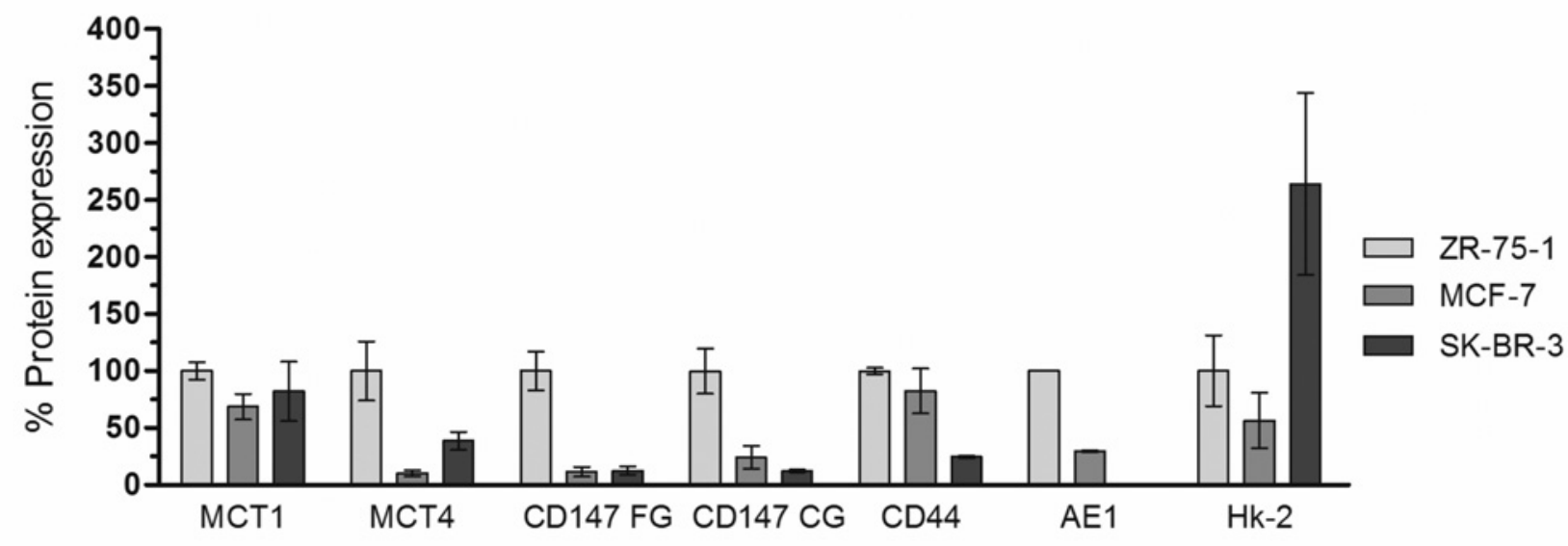

Figure 5 Expression analysis of MCT-1, MCT-4, CD147, CD44, AE1 and Hk-2 in ZR-75-1, MCF-7 and SK-BR-3 breast cancer cell lines cultured in RPMI 1640 medium until $80 \%$ confluence was reached

(A-C) Western blot of all proteins tested as indicated to the left of the blots. $\beta$-Actin was used as a loading control. A representative experiment of at least three independent experiments is shown. (D) Quantification of protein levels. Bands were quantified using ImageJ software and values are expressed as means \pm S.E.M. for at least three independent experiments as a percentage using as reference ZR-75-1 (100\%) (n=3).

the use of MCT-1's specific inhibitor AR-C155858 led to a substantial inhibition of 3BP transport in these cell lines (75$80 \%$ respectively). Interestingly, however, in the SK-BR-3 cell line AR-C155858 inhibits 3BP uptake by only $25 \%$ (Figure 3A). This result is consistent with the behaviour of this cell to the ionophores monensin and valinomycin and reinforces the action of another transport system, distinct from MCTs. The use of the MCT-1 inhibitor AR-C155858 shows that this inhibitor is able to increase the resistance of cells to $3 \mathrm{BP}$ (Figures $3 \mathrm{~B}$ and $3 \mathrm{C}$ ). This indicates a direct relationship between 3BP transport and its cytotoxicity. MCTs, especially MCT-1, are responsible for 3BP uptake that determines the cytotoxic effect of 3BP. We can conclude that if this transport system is blocked, 3BP will not cross the plasma membrane efficiently and cells become resistant to its effects. Although unlikely, we cannot exclude the possibility that some 3BP may enter cells via passive diffusion.

3BP is a substrate of SMCT-1 [28], encoded by the gene $S L C 5 A 8$, the expression of which is down-regulated in many types of cancer. SCMT-1 is now being considered a tumour suppressor [33]. However, we cannot exclude the involvement of SMCT-1 as the sodium-linked symporter for 3BP found in SK-BR-3 cells.

In order to exploit the hypothesis raised, we assessed the expression profiles for MCT-1, MCT-4 and other proteins important for MCTs activity, such as the chaperones CD147 and $\mathrm{CD} 44$, as well as the $\mathrm{pH}$ regulator AE1 (Figure 5). In addition to these proteins, we also assessed the expression of SMCT-1. However, the antibodies commercially available did not give a specific pattern of labelling (results not shown). 
A

ZR-75-1

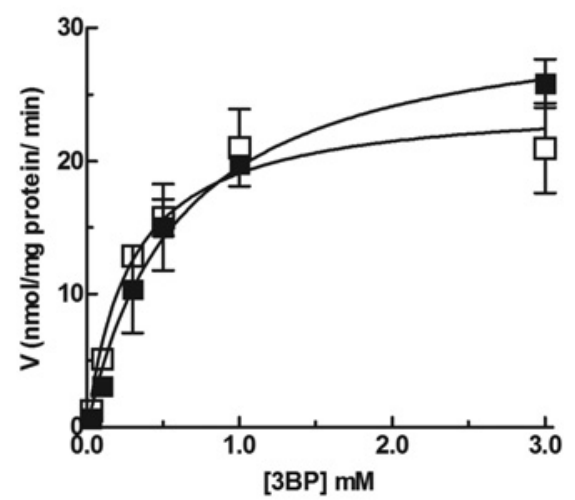

MCF-7

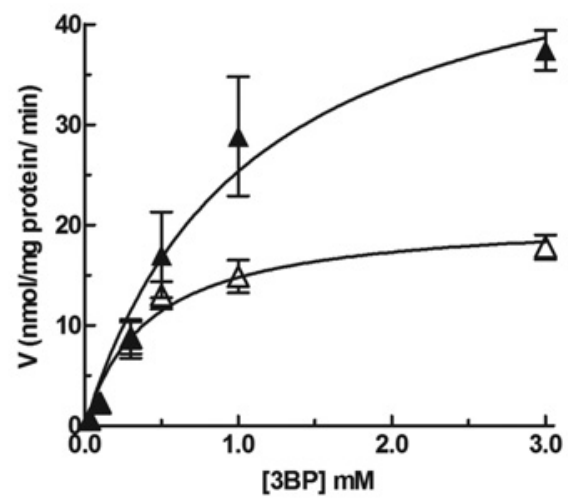

SK-BR-3

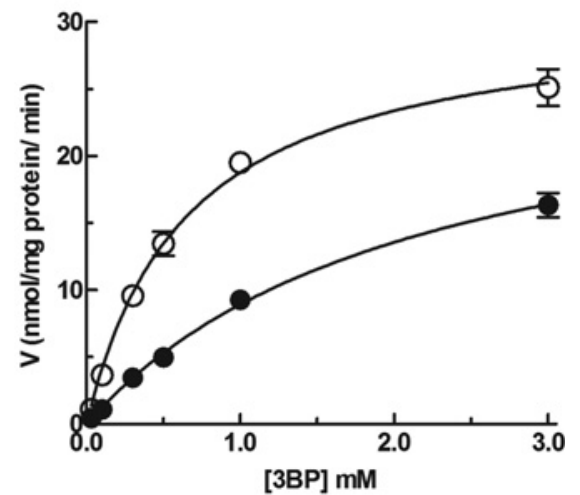

B

\begin{tabular}{|c|c|c|c|}
\hline \multicolumn{2}{|c|}{ Untreated } & $K_{m}(\mathrm{mM})$ & $V_{\max }(\mathrm{nmol} / \mathrm{mg}$ protein/min) \\
\hline $\mathbf{\square}$ & ZR-75-1 & $0.61 \pm 0.15$ & $31 \pm 3$ \\
\hline $\boldsymbol{\Delta}$ & MCF-7 & $1.07 \pm 0.35$ & $52 \pm 8$ \\
\hline - & SK-BR-3 & $2.16 \pm 0.28^{\star}$ & $28 \pm 2$ \\
\hline
\end{tabular}

\begin{tabular}{llcc}
\multicolumn{2}{c}{ Treated with butyrate } & $K_{\mathrm{m}}(\mathrm{mM})$ & $V_{\max }(\mathrm{nmol} / \mathrm{mg}$ protein $/ \mathrm{min})$ \\
\cline { 2 - 4 }$\square$ & ZR-75-1 & $0.29 \pm 0.09$ & $25 \pm 2$ \\
\hline$\Delta$ & MCF-7 & $0.41 \pm 0.10$ & $21 \pm 2$ \\
\hline $\mathrm{O}$ & SK-BR-3 & $0.65 \pm 0.07^{\star}$ & $31 \pm 1$ \\
\hline
\end{tabular}

\section{Figure 6 Effect of butyrate treatment on the kinetics of radio labelled 3BP uptake in the breast cancer cell lines ZR-75-1, MCF-7 and SK-BR-3}

(A) Michaelis-Menten plots of the initial uptake rates of radio labelled 3BP uptake, as a function of the acid concentration at pH 6.0. Black symbols refer to untreated condition and open symbols to cells treated with $10 \mathrm{mM}$ of butyrate. (B) Kinetic parameters, as affinity constant $\left(K_{\mathrm{m}}\right)$ and transport capacity $\left(V_{\max }\right)$ for the uptake of 3BP. Values were estimated with GraphPad Prism software based on the non-linear regression for the Michaelis-Menten equation $f[V]=\left(V_{\max } \times[3 \mathrm{BP}]\right) /\left(K_{\mathrm{m}}+[3 \mathrm{BP}]\right)$. Statistical analysis was performed by one-way ANOVA with Tukey's post-hoc test comparing the $K_{\mathrm{m}}$ and $V_{\max }$ values of each cell line. *Significant differences with $P<0.05(n=3)$.

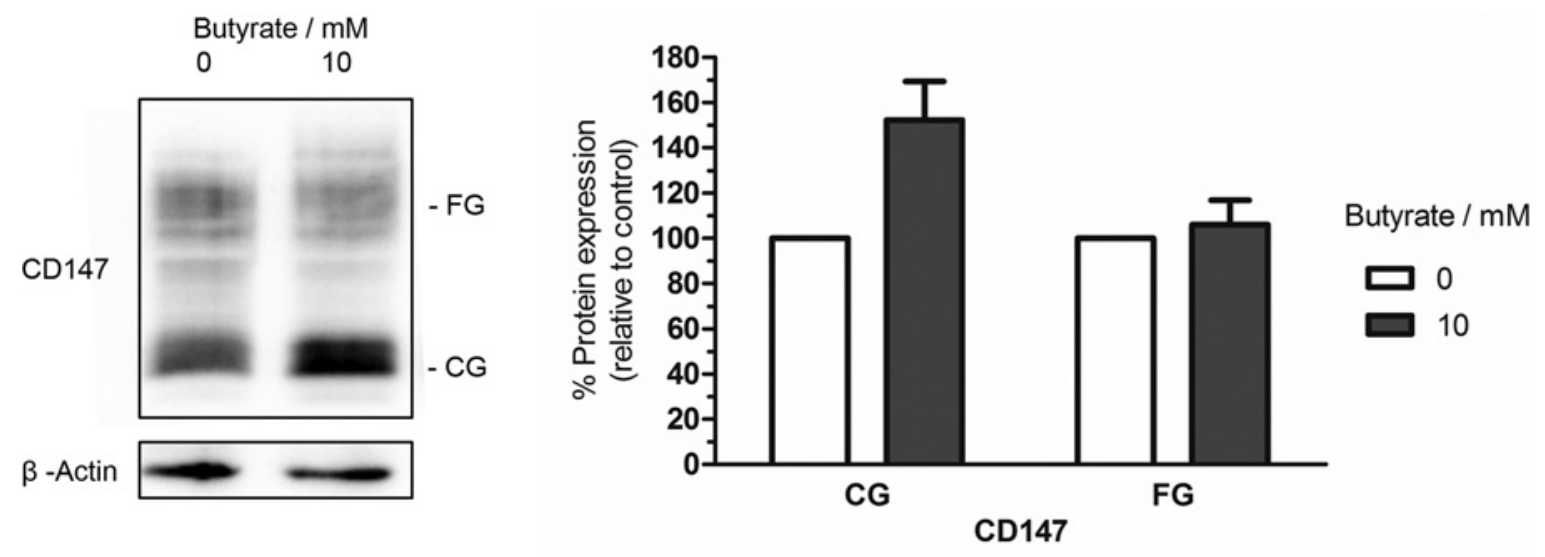

Figure 7 Effect of butyrate treatment on CD147 in breast cancer cell line SK-BR-3

(A) Western blot of CD147 using $\beta$-actin as a loading control in cells untreated (control) and treated with $10 \mathrm{mM}$ butyrate. (B) Quantification of protein levels. Bands were quantified using ImageJ software and values are expressed in comparison with the control sample without butyrate addition $(n=3)$. 
A
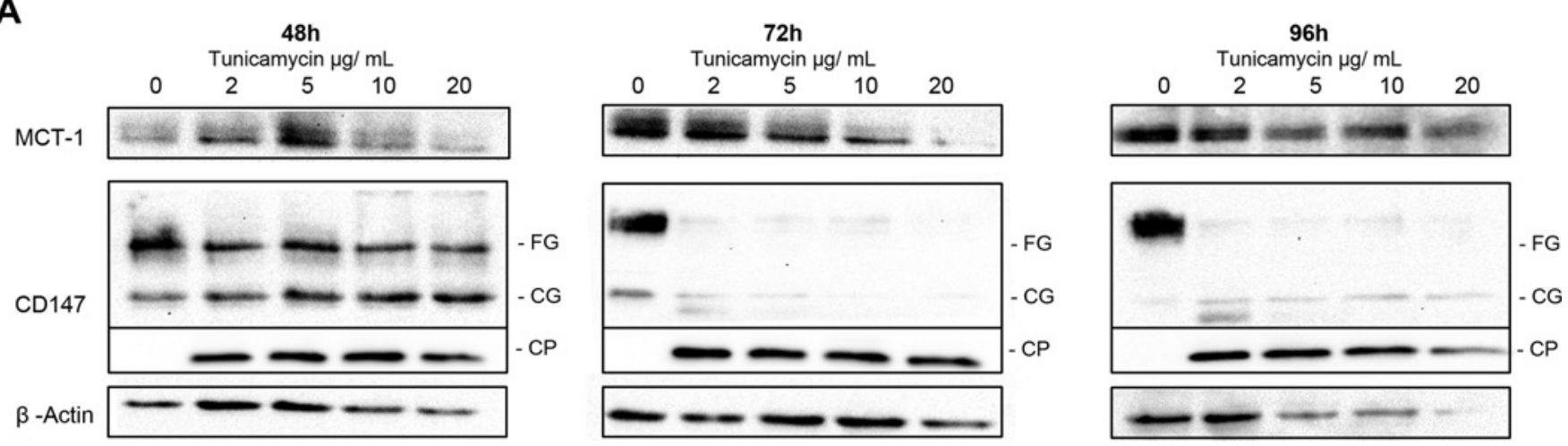

B

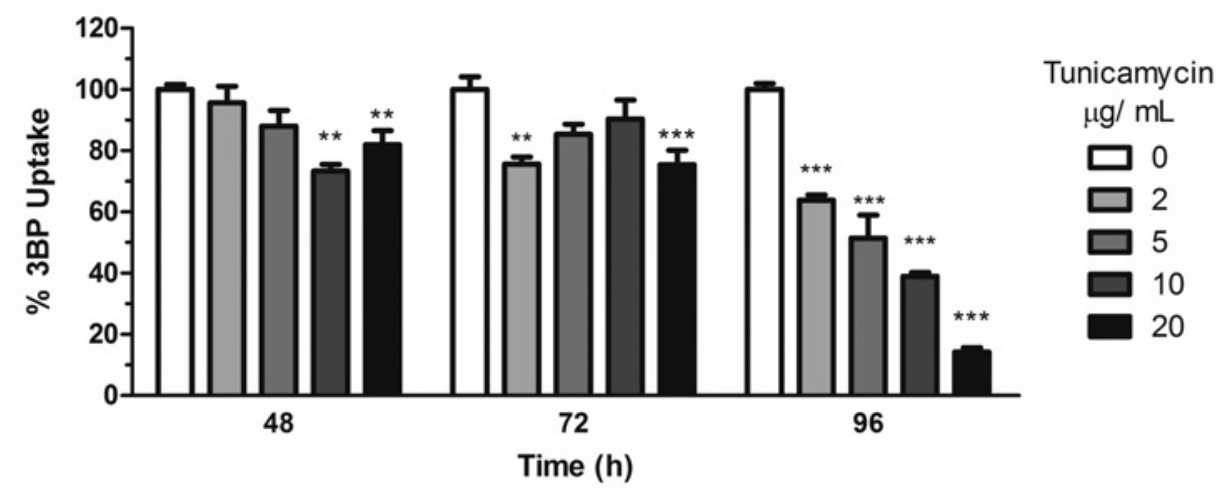

Figure 8 Influence of inhibition of CD147 glycosylation with tunicamycin on 3BP uptake in breast cancer cell line ZR-75-1

(A) Western blot of MCT-1 and CD147 using $\beta$-actin as a loading control at 48, 72 and $96 \mathrm{~h}$ of incubation with tunicamycin. For CD147 detection a low exposure time was used for the CP form and a high exposure time was used for the FG and CG forms of CD147. (B) Inhibition of radiolabelled 3BP (1 mM) uptake by tunicamycin at 2, 5, 10 and $20 \mu \mathrm{g} / \mathrm{ml}$ after 48,72 and $96 \mathrm{~h}$ of treatment. Statistical analysis was performed by two-way ANOVA: ${ }^{\star \star \star}$, ${ }^{\star \star}$ and * indicate significant differences with a respective $P$-values of $<0.001,<0.01$ and $<0.05(n=3)$.

It is known that MCT-1 and MCT-4 activity in the plasma membrane rely on their association with a glycosylated form of CD147 [34]. The binding of CD147 to carbonic anhydrase IV in the extracellular environment has also been reported [35] and that carbonic anhydrases function as proton-collecting antennae supplying protons essential for the activity MCTs [36]. The higher expression of the FG active form of CD147 was observed in ZR-75-1 cells, reinforcing its role on MCT1 and MCT-4 activity and thus in 3BP uptake in these cells.

Another interesting observation was the expression of AE1 found in both ZR-75-1 and MCF-7 cells and its absence from SK-BR-3 cells. AE1 is a known anion exchanger of chloride and bicarbonate, but it was first reported to be involved in the transport of lactate in erythrocytes. Therefore, it may also have a role in 3BP transport. However, we cannot exclude an indirect role for AE1 in proton movement across the plasma membrane, resulting in the activation of an inward flux via MCTs or even its own involvement in the 3BP uptake. The expression of Hk-2, a known target of 3BP [22], was found to be higher in SK-BR-3 cells, the cell line most resistant to 3BP, i.e. more resistant than cell lines ZR-75-1 and MCF-7. Although the SK-BR-3 cell line presented higher levels of Hk-2 expression, the sensitivity to $3 \mathrm{BP}$ can also be related with other intracellular targets such as GAPDH and, as shown in the present study, the equilibrium between acidic extracellular $\mathrm{pH}$ and MCT activity is important for 3BP selectivity and sensitivity to cancer cells.

\section{Butyrate increases the affinity of 3BP transport in SK-BR-3}

Butyrate's anti-cancer properties have been reported previously [37]. However, the molecular mechanism(s) underlying its anticancer properties are still unsolved. Nevertheless, some important advances have been made [38]. Butyrate has a dual role. In normal cells, such as colonocytes, it is used as an energy source, having a positive effect leading to proliferation and differentiation. On the other hand, in colon cancer cells that present the Warburg effect, high concentrations of butyrate are able to initiate apoptotic events [38]. Our previous data showed that butyrate has the ability to sensitize the 3BP-resistant cell line SK-BR-3 to the effect of 3BP by inducing an increased expression of MCT-4 and an enhanced level of MCT-1 localization at the plasma membrane [27]. In addition, we observed that the CD147 expression profile changed with an enhancement of glycosylation upon treatment of cells with butyrate (Figure 7). Finally, we demonstrated that these events are accompanied also by an increase in the affinity for 3BP uptake (Figure 6). This indicates that the effect of butyrate in mediating 3BP uptake is related not only to the over-expression of MCTs at the plasma membrane as previously demonstrated [27], but also 
accompanied by an increase in the affinity for its transport across the plasma membrane. Thus, butyrate sensitizes SK-BR-3 cells to 3BP by promoting MCT-1 re-localization to the plasma membrane with CD147 glycosylation contributing to MCT-1 activity that ultimately promotes cells' uptake of 3BP with increased affinity.

\section{Inhibition of CD147 glycosylation affects 3BP uptake in ZR-75-1}

Our data showed that butyrate stimulated the glycosylation of CD147 and thus we hypothesized that this could lead to an increase in the expression levels of MCT-1 and consequently to the observed higher affinity of 3BP uptake in the resistant cell line SK-BR-3 (Figure 6). To provide further independent evidence on the importance of CD147 glycosylation for MCT-1 expression and activation, we inhibited glycosylation of CD147 using tunicamycin. This compound is a known inhibitor of $\mathrm{N}$ glycosylation and has been previously used to inhibit CD147 glycosylation [39]. In the present study, we have used the ZR-751 cell line, as in contrast with SK-BR-3, it presents higher levels of CD147 as well as higher affinity for 3BP uptake. Our results demonstrate that inhibition of CD147 glycosylation resulted in a decrease in 3BP uptake (Figure 8). The effect was more pronounced with the increased time of exposition to tunicamycin as some active CD147 remains in cells, probably due to a high stability of this protein at the plasma membrane. We could also demonstrate that alterations in CD147 glycosylation lead to a decrease in the expression levels of MCT-1. This observation was expected since these two proteins are tightly associated, being important for monocarboxylic acid uptake [34]. Taken together, the results obtained in both cell lines ZR-75-1 and SK-BR-3 regarding CD147 glycosylation make is possible to postulate that the presence of glycosylated CD147 is crucial for MCT-1mediated transport of 3BP across the plasma membrane. Our data suggest for the first time that glycosylated CD147 is a key factor on the control of the expression levels of MCT-1 and consequently the uptake of 3BP.

\section{Final remarks}

The alkylating agent 3BP has been proposed as a novel anti-cancer drug that targets one of the oldest known phenotypes of cancer, i.e. the Warburg effect. By targeting both key glycolytic enzymes overexpressed in cancers, such as Hk-2 and GAPDH, as well as other targets in mitochondria [23], 3BP is a good candidate for inducing a metabolic catastrophe in cancer cells [40]. Although the highly reactive nature of 3BP may make it appear unsuitable as an anti-cancer agent, several in vivo studies have reported low or no major side effects $[22,25,41,42]$. The overexpression of MCT1 and MCT-4 in tumours has been noted not only by our group but also by others to be a key player in 3BP transport across the plasma membrane, with a major role attributed to MCT- 1 in this process $[26,27,43]$.

In the present study, we show for the first time in cancer cells that the mediated transport of 3BP by MCTs, especially MCT-1 associated with CD147 glycosylation, is a key factor in 3BP's selective anti-cancer effect; however, this is not the only event involved. Our novel results showed that the acidic extracellular $\mathrm{pH}$, which characterizes the tumour extracellular microenvironment, is also crucial for the selective action of $3 \mathrm{BP}$ explaining the selectivity of this potent and promising anti-cancer agent. The acidic microenvironment is a double-edged sword. On the one hand, it provides an advantage for the cancer cells by favouring proliferation and metastasis. However, on the other hand, in the world's fight against cancer, it can be envisaged as an 'Achilles heel' of cancer that can be further explored with the objective of designing/developing new therapeutic approaches to target this hallmark of the cancer, i.e. the Warburg effect.

\section{AUTHOR CONTRIBUTION}

João Azevedo-Silva performed the experiments; Ana Ribeiro participated in the western blot analysis; Odília Queirós and Fátima Baltazar participated in the discussion and organization of the experiments; Margarida Casal, Ana Preto, Ko Young and Peter Pedersen conceived the study and designed the experiments; João Azevedo-Silva, Ana Preto and Margarida Casal wrote the paper.

\section{ACKNOWLEDGEMENTS}

We are especially grateful to Professor André Goffeau for his encouragement throughout the work and critical analysis of the manuscript. We thank AstraZeneca for kindly providing AR-C155858.

\section{FUNDING}

This work was financed by national funds from FEDER (Fundo Europeu de Desenvolvimento Regional), through POFC (Programa Operacional Factores de Competitividade) COMPETE, and by Portuguese National Funds from FCT (Fundação para a Ciência e Tecnologia) in the scope of the project PEst-OE/BIA/U14050/2014. JAS [grant number SFRH/BD/76038/2011] received a fellowship from the Portuguese government from the FCT through FSE (Fundo Social Europeu) and POPH (Programa Operacional Potencial Humano).

\section{REFERENCES}

1 Hanahan, D. and Weinberg, R.A. (2011) Hallmarks of cancer: the next generation. Cell 144, 646-674 CrossRef PubMed

2 Warburg, 0. (1956) On the origin of cancer cells. Science 123, 309-314 CrossRef PubMed

3 Vander Heiden, M.G., Cantley, L.C. and Thompson, C.B. (2009) Understanding the Warburg effect: the metabolic requirements of cell proliferation. Science 324, 1029-1033 CrossRef PubMed

4 Pastorino, J.G., Shulga, N. and Hoek, J.B. (2002) Mitochondrial binding of hexokinase II inhibits Bax-induced cytochrome c release and apoptosis. J. Biol. Chem. 277, 7610-7618 CrossRef PubMed

5 Mathupala, S.P., Rempel, A. and Pedersen, P.L. (1995) Glucose catabolism in cancer cells. Isolation, sequence, and activity of the promoter for type II hexokinase. J. Biol. Chem. 270, 16918-16925 CrossRef PubMed

6 Mathupala, S.P., Ko, Y.H. and Pedersen, P.L. (2006) Hexokinase II: cancer's double-edged sword acting as both facilitator and gatekeeper of malignancy when bound to mitochondria. Oncogene 25, 4777-4786 CrossRef PubMed

7 Guo, C., Liu, S. and Sun, M.Z. (2013) Novel insight into the role of GAPDH playing in tumor. Clin. Transl. Oncol. 15, 167-172 CrossRef PubMed

8 Szablewski, L. (2013) Expression of glucose transporters in cancers. Biochim. Biophys. Acta 1835, 164-169 PubMed

9 Pinheiro, C., Longatto-Filho, A., Azevedo-Silva, J., Casal, M., Schmitt, F.C. and Baltazar, F. (2012) Role of monocarboxylate transporters in human cancers: state of the art. J Bioenerg. Biomembr. 44, 127-139 CrossRef PubMed

10 Pinheiro, C., Reis, R.M., Ricardo, S., Longatto-Filho, A., Schmitt, F. and Baltazar, F. (2010) Expression of monocarboxylate transporters 1,2, and 4 in human tumours and their association with CD147 and CD44. J. Biomed. Biotechnol. 2010, 427694 CrossRef PubMed

11 Tsai, H.J. and Wilson, J.E. (1996) Functional organization of mammalian hexokinases: both $\mathrm{N}$ - and $\mathrm{C}$-terminal halves of the rat type II isozyme possess catalytic sites. Arch. Biochem. Biophys. 329, 17-23 CrossRef PubMed

12 Halestrap, A.P. and Meredith, D. (2004) The SLC16 gene family-from monocarboxylate transporters (MCTs) to aromatic amino acid transporters and beyond. Pflugers Arch. $\mathbf{4 4 7}$ 619-628 CrossRef PubMed

13 Pinheiro, C., Longatto-Filho, A., Ferreira, L., Pereira, S.M., Etlinger, D., Moreira, M.A., Jube, L.F., Queiroz, G.S., Schmitt, F. and Baltazar, F. (2008) Increasing expression of monocarboxylate transporters 1 and 4 along progression to invasive cervical carcinoma. Int. J. Gynecol. Pathol. 27, 568-574 $\underline{\text { CrossRef PubMed }}$ 
14 de Oliveira, A.T., Pinheiro, C., Longatto-Filho, A., Brito, M.J., Martinho, O., Matos, D., Carvalho, A.L., Vazquez, V.L., Silva, T.B., Scapulatempo, C. et al. (2012) Co-expression of monocarboxylate transporter 1 (MCT1) and its chaperone (CD147) is associated with low survival in patients with gastrointestinal stromal tumors (GISTs). J. Bioenerg. Biomembr. 44, 171-178 CrossRef PubMed

15 Pinheiro, C., Sousa, B., Albergaria, A., Paredes, J., Dufloth, R., Vieira, D., Schmitt, F. and Baltazar, F. (2011) GLUT1 and CAIX expression profiles in breast cancer correlate with adverse prognostic factors and MCT1 overexpression. Histol. Histopathol. 26 1279-1286 PubMed

16 Pertega-Gomes, N., Vizcaino, J.R., Miranda-Goncalves, V., Pinheiro, C., Silva, J., Pereira, H., Monteiro, P., Henrique, R.M., Reis, R.M., Lopes, C. and Baltazar, F. (2011) Monocarboxylate transporter 4 (MCT4) and CD147 overexpression is associated with poor prognosis in prostate cancer. BMC Cancer 11, 312 CrossRef PubMed

17 Gallagher, S.M., Castorino, J.J., Wang, D. and Philp, N.J. (2007) Monocarboxylate transporter 4 regulates maturation and trafficking of CD147 to the plasma membrane in the metastatic breast cancer cell line MDA-MB-231. Cancer Res. 67, 4182-4189 CrossRef PubMed

18 Philp, N.J., Yoon, H. and Grollman, E.F. (1998) Monocarboxylate transporter MCT1 is located in the apical membrane and MCT3 in the basal membrane of rat RPE. Am. J. Physiol. 274, R1824-R1828 PubMed

19 Miranda-Goncalves, V., Honavar, M., Pinheiro, C., Martinho, O., Pires, M.M., Cordeiro, M., Bebiano, G., Costa, P., Palmeirim, I., Reis, R.M. and Baltazar, F. (2013) Monocarboxylate transporters (MCTs) in gliomas: expression and exploitation as therapeutic targets. Neuro Oncol. 15, 172-188 CrossRef PubMed

20 Le Floch, R., Chiche, J., Marchiq, I., Naiken, T., IIc, K., Murray, C.M., Critchlow, S.E., Roux, D., Simon, M.P. and Pouyssegur, J. (2011) CD147 subunit of lactate/H + symporters MCT1 and hypoxia-inducible MCT4 is critical for energetics and growth of glycolytic tumors. Proc. Natl. Acad. Sci. U.S.A. 108, 16663-16668 CrossRef PubMed

21 Zhao, Z., Wu, M.S., Zou, C., Tang, Q., Lu, J., Liu, D., Wu, Y., Yin, J., Xie, X., Shen, J. et al. (2013) Downregulation of MCT1 inhibits tumor growth, metastasis and enhances chemotherapeutic efficacy in osteosarcoma through regulation of the NF-kappaB pathway. Cancer Lett. 342, 150-158 CrossRef PubMed

22 Ko, Y.H., Pedersen, P.L. and Geschwind, J.F. (2001) Glucose catabolism in the rabbit VX2 tumor model for liver cancer: characterization and targeting hexokinase. Cancer Lett. 173, 83-91 CrossRef PubMed

23 Pereira da Silva, A.P., El-Bacha, T., Kyaw, N., dos Santos, R.S., da-Silva, W.S., Almeida, F.C., Da Poian, A.T. and Galina, A. (2009) Inhibition of energy-producing pathways of HepG2 cells by 3-bromopyruvate. Biochem. J. 417, 717-726 CrossRef PubMed

24 Ko, Y.H., Smith, B.L., Wang, Y., Pomper, M.G., Rini, D.A., Torbenson, M.S., Hullihen, J. and Pedersen, P.L. (2004) Advanced cancers: eradication in all cases using 3-bromopyruvate therapy to deplete ATP. Biochem. Biophys. Res. Commun. 324, 269-275 CrossRef PubMed

25 Ko, Y.H., Verhoeven, H.A., Lee, M.J., Corbin, D.J., Vogl, T.J. and Pedersen, P.L. (2012) A translational study "case report" on the small molecule "energy blocker" 3-bromopyruvate (3BP) as a potent anticancer agent: from bench side to bedside. J. Bioenerg. Biomembr. 44, 163-170 CrossRef PubMed

26 Birsoy, K., Wang, T., Possemato, R., Yilmaz, O.H., Koch, C.E., Chen, W.W., Hutchins, A.W., Gultekin, Y., Peterson, T.R., Carette, J.E. et al. (2013) MCT1-mediated transport of a toxic molecule is an effective strategy for targeting glycolytic tumors. Nat. Genet. $\mathbf{4 5}$, 104-108 CrossRef PubMed

27 Queiros, O., Preto, A., Pacheco, A., Pinheiro, C., Azevedo-Silva, J., Moreira, R., Pedro, M., Ko, Y.H., Pedersen, P.L., Baltazar, F. and Casal, M. (2012) Butyrate activates the monocarboxylate transporter MCT4 expression in breast cancer cells and enhances the antitumor activity of 3-bromopyruvate. J. Bioenerg. Biomembr. 44, 141-153 CrossRef PubMed

Received 22 July 2014/14 January 2015; accepted 2 February 2015

Published as BJ Immediate Publication 2 February 2015, doi:10.1042/BJ20140921
28 Thangaraju, M., Karunakaran, S.K., Itagaki, S., Gopal, E., Elangovan, S., Prasad, P.D. and Ganapathy, V. (2009) Transport by SLC5A8 with subsequent inhibition of histone deacetylase 1 (HDAC1) and HDAC3 underlies the antitumor activity of 3-bromopyruvate. Cancer 115, 4655-4666 CrossRef PubMed

29 Kobayashi, M., Itagaki, S., Hirano, T. and Iseki, K. (2004) Mechanism of L-lactic acid transport in L6 skeletal muscle cells. Drug Metab. Pharmacokinet. 19, 363-368 CrossRef PubMed

30 Ovens, M.J., Davies, A.J., Wilson, M.C., Murray, C.M. and Halestrap, A.P. (2010) AR-C155858 is a potent inhibitor of monocarboxylate transporters MCT1 and MCT2 that binds to an intracellular site involving transmembrane helices 7-10. Biochem. J. $\mathbf{4 2 5}$ 523-530 CrossRef PubMed

31 Sonveaux, P., Vegran, F., Schroeder, T., Wergin, M.C., Verrax, J., Rabbani, Z.N., De Saedeleer, C.J., Kennedy, K.M., Diepart, C., Jordan, B.F. et al. (2008) Targeting lactate-fueled respiration selectively kills hypoxic tumor cells in mice. J. Clin. Invest. 118, 3930-3942 PubMed

32 Majkowska-Skrobek, G., Augustyniak, D., Lis, P., Bartkowiak, A., Gonchar, M., Ko, Y.H., Pedersen, P.L., Goffeau, A. and Ulaszewski, S. (2014) Killing multiple myeloma cells with the small molecule 3-bromopyruvate: implications for therapy. Anticancer Drugs $\mathbf{2 5}$, 673-682 PubMed

33 Li, H., Myeroff, L., Smiraglia, D., Romero, M.F., Pretlow, T.P., Kasturi, L., Lutterbaugh, J., Rerko, R.M., Casey, G., Issa, J.P. et al. (2003) SLC5A8, a sodium transporter, is a tumor suppressor gene silenced by methylation in human colon aberrant crypt foci and cancers. Proc. Natl. Acad. Sci. U.S.A. 100, 8412-8417 CrossRef PubMed

34 Kirk, P., Wilson, M.C., Heddle, C., Brown, M.H., Barclay, A.N. and Halestrap, A.P. (2000) CD147 is tightly associated with lactate transporters MCT1 and MCT4 and facilitates their cell surface expression. EMBO J. 19, 3896-3904 CrossRef PubMed

35 Klier, M., Andes, F.T., Deitmer, J.W. and Becker, H.M. (2013) Intracellular and extracellular carbonic anhydrases cooperate non-enzymatically to enhance activity of monocarboxylate transporters. J. Biol. Chem. 289, 2765-2775 CrossRef PubMed

36 Becker, H.M., Klier, M., Schuler, C., McKenna, R. and Deitmer, J.W. (2011) Intramolecular proton shuttle supports not only catalytic but also noncatalytic function of carbonic anhydrase II. Proc. Natl. Acad. Sci. U.S.A. 108, 3071-3076 CrossRef PubMed

37 Fung, K.Y., Cosgrove, L., Lockett, T., Head, R. and Topping, D.L. (2012) A review of the potential mechanisms for the lowering of colorectal oncogenesis by butyrate. Br. J. Nutr. 108, 820-831 CrossRef PubMed

38 Donohoe, D.R., Collins, L.B., Wali, A., Bigler, R., Sun, W. and Bultman, S.J. (2012) The Warburg effect dictates the mechanism of butyrate-mediated histone acetylation and cell proliferation. Mol. Cell 48, 612-626 CrossRef PubMed

39 Tang, W., Chang, S.B. and Hemler, M.E. (2004) Links between CD147 function, glycosylation, and caveolin-1. Mol. Biol. Cell 15, 4043-4050 CrossRef PubMed

40 Parks, S.K., Chiche, J. and Pouyssegur, J. (2013) Disrupting proton dynamics and energy metabolism for cancer therapy. Nat. Rev. Cancer 13,611-623 CrossRef PubMed

41 Vossen, J.A., Buijs, M., Syed, L., Kutiyanwala, F., Kutiyanwala, M., Geschwind, J.F. and Vali, M. (2008) Development of a new orthotopic animal model of metastatic liver cancer in the rabbit VX2 model: effect on metastases after partial hepatectomy, intra-arterial treatment with 3-bromopyruvate and chemoembolization. Clin. Exp. Metastasis 25, 811-817 CrossRef PubMed

42 Schaefer, N.G., Geschwind, J.F., Engles, J., Buchanan, J.W. and Wahl, R.L. (2012) Systemic administration of 3-bromopyruvate in treating disseminated aggressive lymphoma. Transl. Res. 159, 51-57 CrossRef PubMed

43 Matsumoto, S., Saito, K., Yasui, H., Morris, H.D., Munasinghe, J.P., Lizak, M., Merkle, H., Ardenkjaer-Larsen, J.H., Choudhuri, R., Devasahayam, N. et al. (2013) EPR oxygen imaging and hyperpolarized 13C MRI of pyruvate metabolism as noninvasive biomarkers of tumor treatment response to a glycolysis inhibitor 3-bromopyruvate. Magn. Reson. Med. 69, 1443-1450 CrossRef PubMed 